DOI: $\underline{\text { https://doi.org/10.31933/dijms.v2i3 }}$

Received: 3 January 221, Revised: 15 January 2021, Publish: 15 February 2021

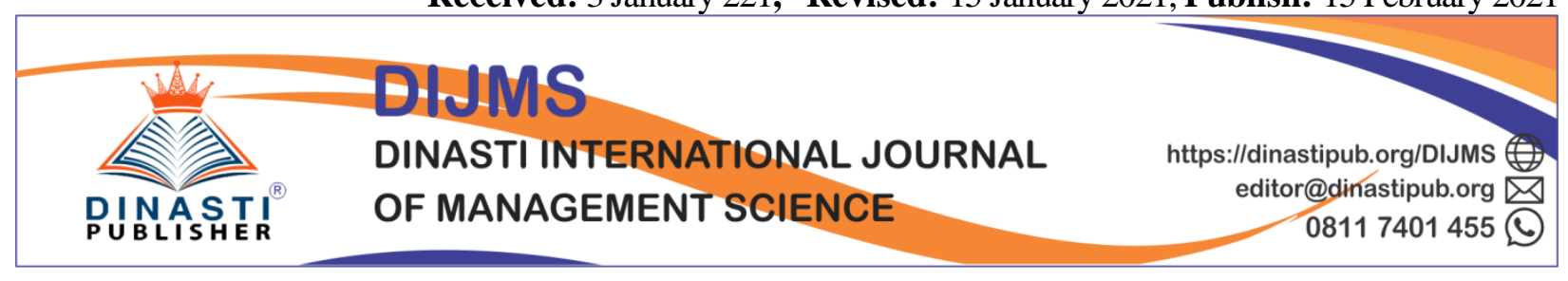

\title{
DETERMINATION OF TRUST AND PURCHASE DECISIONS: ANALYSIS OF BRAND IMAGE AND PRICE (MARKETING MANAGEMENT LITERATURE REVIEW)
}

\author{
Wydyanto Wydyanto ${ }^{1}$, Ridho Rafqi Ilhamalimy ${ }^{2}$ \\ ${ }^{1)} \mathrm{Ph}$.D Student, Institute of Visual Informatic, University Kebangsaan Malaysia, Selangor, Malaysia, \\ email:p93043@siswa.ukm.edu.my \\ 1) Departement of Computer Science, Universitas Bina Darma, Sumatera Selatan 30264, Indonesia, \\ wydyanto@binadarma.ac.id \\ ${ }^{2}$ Student of Magister Management, Universitas Mercu Buana Jakarta. \\ Rafqiridho@gmail.com
}

\begin{abstract}
The purpose of writing a Literature Review Papers is to determine the effect of brand image and price variables on trust and purchase decisions. With qualitative methods and Library Research. The results show that brand image affects on trust, brand image affects on purchasing decision, price affects on trust, price affects on purchasing decision and trust affects on purchasing decisions.
\end{abstract}

Keywords: Brand Image, Price, Trust, Purchase Decisions.

\section{INTRODUCTION}

Every student, both undergraduate, undergraduate and undergraduate, is required to conduct research in the form of a thesis, thesis and dissertation. Likewise for lecturers, researchers and other functional personnel who are active in conducting research and publishing scientific articles for publication in scientific journals.

Based on the empirical experience of many young students and lecturers as well as other researchers, it is difficult to find supporting articles in research as previous research or as relevant research. Articles as relevant researchers are needed to strengthen the theory under study, to see the relationship between variables and to build hypotheses, also very much needed in the discussion of research results.

This article discusses the effect of brand image and price on trust and its impact on purchasing decisions, (A Study of Marketing Management Literature). Of course, not all factors affect Work Motivation and Employee Performance in this article, only a small part will be reviewed and reviewed. 
In detail, the purpose of writing this "Literature Review Paper" is to determine the effect of exogenous variables on brand image and price on endogenous variables, trust and purchase decisions.

1) The effect of brand image on trust

2) The effect of brand image on purchasing decisions

3) The effect of price on trust

4) The effect of price on purchasing decisions

5) The effect of trust on purchasing decisions

\section{THEORITICAL REVIEW}

\section{Purchase decision}

Purchasing decision, is the selection of two or more alternative purchasing decision choices, which means that someone can make a decision, there must be several alternative choices. The decision to buy can lead to how the decision-making process is carried out (Schiffman and Kanuk, 2009: 30). This is in line with (Sumarwan, 2011: 357) explaining that a purchase decision is a decision as the selection of an action from two or more alternative choices. Another case with (Kotler, 2012: 166) explaining the purchase decision is a purchase decision process consisting of five stages carried out by a consumer before arriving at a purchase decision and then postpurchase. Consumer behavior will look at the behavior of each individual, household or organization about how they process before making a purchase decision, as well as their actions after obtaining and consuming products, services or ideas. Based on the description above, it can be summarized that consumer decision making is a process that collects and combines information and knowledge to evaluate two or more alternative behaviors and choose one of them which can be seen from each individual or organization how the process is before making a purchase.

\section{Purchasing Decision Process}

According to Kotler and Armstrong (2012: 176) consumers will go through 5 (five) stages of the purchase decision process. These stages can be seen in the Figure below.

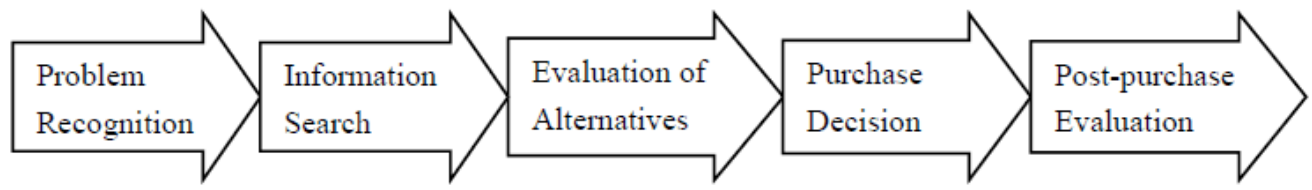

Figure 1. Model Decision Making Process

Source: Kotler dan Armstrong (2012:176)

Based on the decision-making process model above, the following is an explanation of the five stages (Kotler and Armstrong, 2012: 176), namely:

1) Problem Recognition

The buying process starts when the buyer recognizes a problem or need. The recognition of this need is intended to identify unmet and unfulfilled needs and wants.

2) Information Search

An already interested consumer might be looking for more information but maybe not. Consumers can get information from several sources, including: 
a) Personal Resources: Family, friends, neighbors.

b) Commercial sources: Advertisements, salespeople, agents, packaging, displays.

c) Public Sources: Mass media, consumer assessment organizations.

d) Source of Experience: Handling, inspection, use of the product.

3) Evaluation of Alternatives

The stage of the buyer's decision, which is when consumers use the information to evaluate alternative brands in the choice of device. This evaluation cannot be separated from the influence of the resources at hand (time, money, information) or the risk of wrong selection.

4) Purchase Decision

In the evaluation stage, consumers form preferences for brands that are in the choice set. Consumers can also form an intention to buy, because of loyalty to the chosen brand.

5) Post Purchase Behavior

The stage of the purchase decision process, which is when consumers take further action after purchasing based on satisfaction.

Indicators of purchasing decisions from previous research such as(Yunita \& Ali, 2017) use five indicators, namely:1) Product introduction; 2) Search Information; 3) Alternative evaluation; 4) Purchase Decision; 5) Post-Purchase Behavior.

Purchasing decisions have been researched by many previous researchers, including by ( $\mathrm{Yu}$ et al., 2013), (Ali, 2019a), (Rosyid et al., 2013), (Kazmi \& Mehmood, 2016), (Sivaram et al., 2019), (Chovanová et al., 2015) (Durrani et al., 2015) (Foster, 2017). (Suhaily, 2017) (Dudu \& Agwu, 2014), (Anggita \& Ali, 2017), (Novansa \& Ali, 2017), (Brata et al., 2017), (Djatmiko \& Pradana, 2016), (Gan \& Wang, 2017), (Yunita \& Ali, 2017), (Rosyid et al., 2013) (Rödiger et al., 2016), (Amanah et al., 2017),(Konuk, 2018), (Ferdinand, 2014)(Larasetiati \& Ali, 2019), (Firmansyah \& Ali, 2019), (Zhao et al., 2019), (Jeaheng et al., 2020), (Damghanian et al., 2016), (Al-ekam, 2016), (Yen, 2019).

\section{Trust}

Consumer trust is defined as the knowledge that consumers have from the conclusions made about objects, attributes, and benefits (Mowen, 2012). According to Gunawan (2013), trust is defined as a form of attitude that shows feelings of liking and persists in using a product or brand. Trust will arise from the minds of consumers if the product purchased is able to provide the benefits or value that consumers want in a product. Consumer trust means that all knowledge possessed by consumers and all conclusions made by consumers regarding objects, attributes and benefits (According to Mowen and Minor, 2002). According to Siagian and Cahyono (2014), trust is a belief from one party regarding the intentions and behavior aimed at the other party. Aribowo and Nugroho (2013) argue that the trust of certain parties to other parties concerned in conducting transaction relationships is based on a the belief that the person he trusts will fulfill all his obligations properly as expected. From the description above, it can be concluded that trust is the knowledge that consumers have about the benefits of a product that can affect the kinsmen to like and keep using the product.

Research by (Pappas, 2018) using four indicators in measuring trust, including: 1) Trustworthiness; 2) Reliable; 3) Have high integrity; 4) Competent and knowledgeable.

Research on trust has been widely studied by previous studies such as research developed by (Brata et al., 2017), (Al-ekam, 2016), (Setiawan et al., 2020), (Amanah et al., 2017), (Yen, 2019), (Jeaheng et al., 2020), (Konuk, 2018), (Suhaily, 2017), (Susanty et al., 2016), (Larasetiati \& 
Ali, 2019), (Firmansyah \& Ali, 2019), (Zhao et al., 2019), ( Mosunmola et al., 2019), (Jeaheng et al., 2020), (Damghanian et al., 2016), (Al-ekam, 2016), (Yen, 2019).

\section{Brand Image}

Brand image is a perception that is relatively consistent in the long term, so it is not easy to form an image, and once an image is formed it will be difficult to change it. The image formed must be clear and have a brand advantage over other brands. The formation of a brand image is also influenced by consumer experience. Basically, the brand is important in marketing a product. Producers must be able to produce a brand that is easily recognized, so that consumers can always remember it with a good image, which will then emerge a brand image (Simamora, 2011: 33). According to (Kotler and Keller, 2016) Brand image is the consumer's perception of a brand as a reflection of the associations that exist in the minds of consumers. Brand image is an association that appears in the minds of consumers when they remember a particular brand. These associations can simply appear in the form of thoughts and images associated with a brand. The image of the brand is related to attitudes in the form of beliefs and preferences for a brand. Consumers who have a positive image of a brand are more likely to make purchases (Setiadi, 2003: 180). Thus the conclusion of the brand image is the consumer's perception of a brand that consumers can always remember, where the good and bad image built by the brand will be able to influence consumer behavior in making purchases.

Research by (Kim et al., 2019) using four indicators in measuring brand image, including: 1) prestige; 2) reach high standards; 3) good service provision; 4) nice design.

Research on Brand Image has been widely studied by previous studies such as research developed by (M \& Ali, 2017), (Ali, 2019a), (Setyadi \& Ali, 2017), (Agussalim \& Ali, 2017), (Cheong \& Jang, 2008), (Kazmi \& Mehmood, 2016), (Yu et al., 2013), (Rosyid et al., 2013), (Kazmi \& Mehmood, 2016)(Kazmi \& Mehmood, 2016)(Kazmi \& Mehmood, 2016)(Kazmi \& Mehmood, 2016)(Sivaram et al., 2019), (Chovanová et al., 2015), (Durrani et al., 2015), (Foster, 2017), (Suhaily, 2017).

\section{Price}

According to Kotler and Keller (2012: 67), price is one element of the marketing mix that generates revenue, another element generates costs. Price is the easiest element in any marketing program to customize, product features, channels, and even communication take a lot of time. Meanwhile, according to Suparyanto and Rosad (2015: 141), price is the amount of something that has a general value in the form of money that must be sacrificed to get a product. According to Assauri (2014: 223), price is the only element of the marketing mix that generates sales revenue, while the other elements are only the cost element. Price is a monetary unit or other measure (including other goods and services) that are exchanged in order to obtain ownership rights or use of goods and services so as to cause consumer satisfaction (Alma, 2011: 169). Based on the description above, it can be concluded that the price is the amount of money charged for a product that consumers exchange for the advantages of the product.Penelitian oleh (Djatmiko \& Pradana, 2016) menggunakan empat indikator dalam mengukur Harga, meliputi:1) fair price; 2) fix price; 3 ) reliable prices; 4) relative price.

Research on prices has been widely studied by previous studies such as research developed by (Brata et al., 2017), (Al-ekam, 2016), (Setiawan et al., 2020), (Amanah et al., 2017), (Yen, 2019), (Jeaheng et al., 2020), (Konuk, 2018), (Suhaily, 2017), (Susanty et al., 2016), (Dudu \& 
Agwu, 2014), (Anggita \& Ali, 2017), (Djatmiko \& Pradana, 2016), (Gan \& Wang, 2017), (Yunita \& Ali, 2017), (Rosyid et al., 2013), (Rödiger et al., 2016), (Ferdinand, 2014)

\section{WRITING METHOD}

The method of writing scientific articles is by qualitative methods and literature study or Library Research. Reviewing literature books in accordance with the theory discussed, especially in the scope of Marketing Management. Besides, it analyzes reputable scientific articles as well as scientific articles from journals that are not yet reputable. All cited scientific articles are sourced from Mendeley and Google Scholar.

In qualitative research, literature review should be used consistently with methodological assumptions. This means that it must be used inductively so that it does not lead to the questions posed by the researcher. One of the main reasons for conducting qualitative research is that it is exploratory in nature, (Ali \& Limakrisna, 2013).

Furthermore, it is discussed in depth in the section entitled "Related Literature" or literature review ("Review of Literature"), as a basis for formulating hypotheses and will then become the basis for making comparisons with the results or findings revealed in the research. (Ali \& Limakrisna, 2013).

\section{DISCUSSION}

\section{The effect of brand image on trust}

The strong brand image in the minds of consumers will increase the trust felt by consumers in using the products they buy ( $M \&$ Ali, 2017). When consumers are aware that the brand that will be used has more benefits, consumers will believe it (Ali, 2019a), because the brand image and company reputation can be maintained, will lead to buying behavior (Ali, 2019a). Brand image has aspects that can be formed through access to services, services offered, personal contact, security, and positive reputation can affect consumer trust and commitment. (Setyadi \& Ali, 2017). A strong brand image indicates that consumers will trust the product they buy (Agussalim \& Ali, 2017). Brand image significantly affects the trust accepted by consumers (Cheong \& Jang, 2008). Brand image affects the image that arises in consumer memory (Kazmi \& Mehmood, 2016). (Suhaily, 2017) Brand image has a positive and significant effect on customer trust.

\section{The effect of brand image on purchasing decisions}

Brand image has a positive impact on purchasing decisions (Yu et al., 2013). Brand image, brand awareness and price factors can positively influence the buying behavior of a product (Ali, 2019a). (Rosyid et al., 2013) Brand image has a positive effect on purchasing decisions. Brand image for purchasing electronic products has a positive correlation and has a significant effect on purchase intention (Kazmi \& Mehmood, 2016). Increasing the positive image of the brand will have an impact on purchasing decisions (Sivaram et al., 2019). As well as (Chovanová et al., 2015) that the brand has an impact on the customer's decision-making process. As for (Durrani et al., 2015) brand image has a positive relationship with purchasing behavior. (Foster, 2017) Brand image has a positive influence on purchasing decisions. (Suhaily, 2017) Brand image has a positive and significant effect on purchasing decisions.

\section{The effect of price on trust}

Price is one of the determinants of a company's success because it determines how much profit the company will get (Brata et al., 2017). Competitive prices can create consumer trust (Al- 
ekam, 2016). (Setiawan et al., 2020) find price plays an important role in building customer trust.(Amanah et al., 2017) The research results show that price and trust are positive and can significantly influence online purchasing decisions. As for the results (Yen, 2019) found that price has a large influence on trust.(Jeaheng et al., 2020) price has a positive and significant effect on trust. (Konuk, 2018) price has a positive effect on trust. (Suhaily, 2017) price has a positive and significant effect on customer trust. As well as (Susanty et al., 2016) price has a significant positive effect on individual trust.

\section{The effect of price on purchasing decisions}

Companies must pay attention to prices from competitors because they can influence the behavior of purchasing decisions (Dudu \& Agwu, 2014). Price is also one of the determinants of consumers in determining purchasing decisions for products or services (Anggita \& Ali, 2017), The correlation shows that each dimension of the price variable with the purchase decision is related to a positive value (Novansa $\&$ Ali, 2017). Price has a strong correlation coefficient value with purchasing decisions, where it is necessary to pay attention to discounts and price suitability because it can attract purchasing decisions (Brata et al., 2017). Price affects consumer purchasing decisions for a product (Djatmiko \& Pradana, 2016), Research by (Gan \& Wang, 2017) Price perception has a significant positive effect on purchasing decisions. The more competitive the price will increase the purchasing decision (Yunita \& Ali, 2017). (Rosyid et al., 2013) Price has a positive effect on purchasing decisions, companies must focus on communicating customer value through price. As well as (Rödiger et al., 2016) low prices can influence consumers to buy. (Amanah et al., 2017) The research results show that price and trust are positive and can significantly influence online purchasing decisions.(Konuk, 2018; (Ferdinand, 2014) price has a positive effect on purchasing decisions.

\section{The effect of trust on purchasing decisions}

Consumer trust will create good trust in the seller and will increase consumer buying behavior (Larasetiati \& Ali, 2019). Trust has a direct and significant effect on purchase intention (Firmansyah \& Ali, 2019). (Zhao et al., 2019) Trust is an important factor in increasing interest in online shopping. Mosunmola et al. (2019) also found an influence between trust and purchase intention. (Jeaheng et al., 2020) trust has a positive and significant effect on purchasing decisions. (Damghanian et al., 2016) High trust can reduce the perceived risk of consumers so that it can have an impact on purchasing decisions. Trust has a significant positive effect on consumer purchasing decisions (Al-ekam, 2016). And research from (Yen, 2019) found that trust has a significant positive effect on purchasing decisions.

\section{Conceptual Framework}

Based on the formulation of the problem of writing this article and a study of literature reviews from both relevant books and articles, the frame for this article is processed as below. 


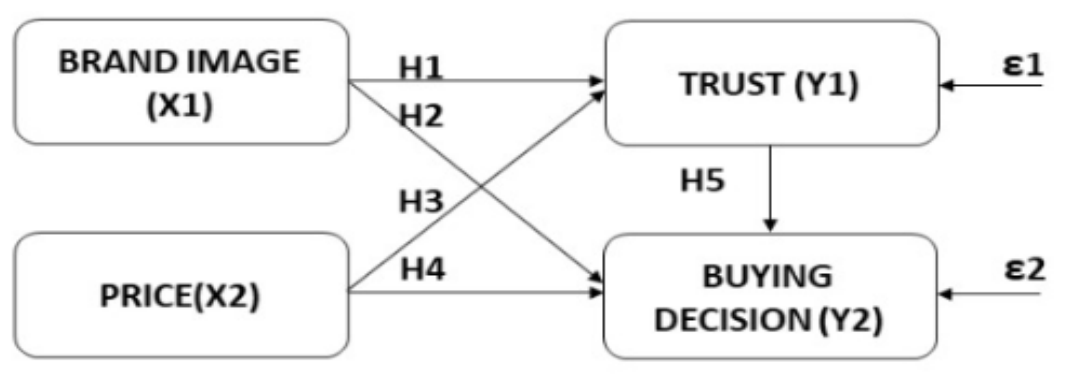

Brand image and price have a relationship and influence trust and purchase decisions, either directly or indirectly.

Apart from the brand image and price variables that affect trust and purchase decisions, there are many other variables that influence it, including the variables:

1) Promotion: (Ali, Evi, et al., 2018), (Prihartono \& Ali, 2020), (Richardo et al., 2020), (Mappesona et al., 2020), (Sulistiorini \& Ali, 2017), (Hairiyah \& Ali, 2017), (Ali, Narulita, et al., 2018), and (Brata et al., 2017).

2) Service quality: (M \& Ali, 2017),(Limakrisna \& Ali, 2016), (Yunita \& Ali, 2017), (Yunita \& Ali, 2017), (Ali \& Mappesona, 2016), (Ali, Evi, et al., 2018), (Sitio \& Ali, 2019), and (Anggita \& Ali, 2017).

3) Product quality: (M \& Ali, 2017), (Ali, Narulita, et al., 2018), (M \& Ali, 2017), (Ali, Evi, et al., 2018), (Prihartono \& Ali, 2020), (Riyanto et al., 2017), (Maisah \& Ali, 2020), (Brata et al., 2017), (Thanh Nguyen et al., 2019), (Ali, 2019), and (Anggita \& Ali, 2017).

\section{CONCLUSIONS AND SUGGESTIONS}

\section{Conclusion}

Hypothesis testing research is research that aims to develop a hypothesis and test it empirically on a particular problem (Ali \& Limakrisna, 2013). Based on the formulation of articles, results and discussion, hypotheses can be formulated for further research:

1. Brand Image affects on Trust.

2. Brand Image affects on Purchasing Decision.

3. Price affects on Trust.

4. Price affects on Purchasing Decision.

5. Trust affects on purchasing Decisions.

\section{Suggestion}

Based on the conclusions above, the suggestion in this article is that there are many other factors that influence trust and purchase decisions, apart from brand image and price in all companies, therefore further study is needed to find what other factors are. only those that can influence trust and purchase decisions other than those examined in this article.

\section{REFERENCES}

Al-ekam, J. M. E. (2016). The mediating effect of brand trust on the influence of communication, price, and product quality on consumer purchase behaviour in a less-developed country. Malaysian Management Journal, 20(December), 87-97.

Ali, H. (2019a). Building Repurchase Intention and Purchase Decision: Brand Awareness and 
Brand Loyalty Analysis (Case Study Private Label Product in Alfamidi Tangerang). Saudi Journal of Humanities and Social Sciences, 04(09), 623-634. https://doi.org/10.36348/sjhss.2019.v04i09.009

Ali, H. (2019b). Purchase Decision and Repurchase Models: Product Quality and Process Analysis (Case Study of House Ownership Credit Financing in Permata Sharia Bank Jakarta). Scholars Bulletin. https://doi.org/10.36348/sb.2019.v05i09.006

Ali, H., Evi, N., \& Nurmahdi, A. (2018). The Influence of Service Quality , Brand Image and Promotion on Purchase Decision at MCU Eka Hospital. Business and Management Studies. https://doi.org/10.21276/sjbms.2018.3.1.12

Ali, H., \& Mappesona, H. (2016). Build brand image: Analysis Service Quality and Product Quality (case study at Giant Citra Raya). International Journal of Economic Research.

Ali, H., Narulita, E., \& Nurmahdi, A. (2018). Saudi Journal of Business and Management Studies ( SJBMS ) The Influence of Service Quality, Brand Image and Promotion on Purchase Decision at MCU Eka Hospital. Business and Management Studies. https://doi.org/10.21276/sjbms.2018.3.1.12

Amanah, D., Hurriyati, R., Gaffar, V., Wibowo, L. A., \& Harahap, D. A. (2017). Which is More Influential in Online Purchasing Decisions : Price or Trust? Which is More Influential in Online Purchasing Decisions: Price or Trust? November. https://doi.org/10.5220/0007090107980803

Anggita, R., \& Ali, H. (2017). The Influence of Product Quality, Service Quality and Price to Purchase Decision of SGM Bunda Milk (Study on PT. Sarihusada Generasi Mahardika Region Jakarta, South Tangerang District). Scholars Bulletin. https://doi.org/10.21276/sb

Brata, B. H., Husani, S., \& Ali, H. (2017). The Importance of Quality Products, Price, Promotion, and Location to Product Purcese Decision on Nitchi At PT. Jaya Swarasa Agung in Central Jakarta. Saudi Journal of Business and Management Studies. https://doi.org/10.21276/sjbms

Cheong \&Jang. (2008). Determinants of Internet Usage in Ghanaian Hotels: The Case of the Greater Accra Region ( GAR ) Determinants of Internet Usage in Ghanaian Hotels : The Case of the Greater Accra Region ( GAR ). Journal of Hospitality \& Leisure Marketing, 15(3), 3741. https://doi.org/10.1300/J150v15n03

Chovanová, H. H., Korshunov, A. I., \& Babčanová, D. (2015). Impact of Brand on Consumer Behavior. Procedia Economics and Finance, 34(9), 615-621. https://doi.org/10.1016/s22125671(15)01676-7

Damghanian, H., Zarei, A., \& Siahsarani Kojuri, M. A. (2016). Impact of Perceived Security on Trust, Perceived Risk, and Acceptance of Online Banking in Iran. Journal of Internet Commerce, 15(3), 214-238. https://doi.org/10.1080/15332861.2016.1191052

Djatmiko, T., \& Pradana, R. (2016). Brand Image and Product Price; Its Impact for Samsung Smartphone Purchasing Decision. Procedia - Social and Behavioral Sciences, 219, 221-227. https://doi.org/10.1016/j.sbspro.2016.05.009

Dudu, O., \& Agwu, M. (2014). A Review of The Effect of Pricing Strategies on The Purchase of Consumer Goods. International Journal of Research in Management, Science \& Technology, 2(2), 88-102. 
Ferdinand, T. dan. (2014). Analyzing the Influence of Price and Product Quality on Buying Decision. Jurnal EMBA, 2(3), 1255-1263.

Firmansyah, N., \& Ali, H. (2019). Consumer Trust Model: The Impact of Satisfaction and EService Quality toward Repurchase Intention in E-Commerce. 6256, 552-559. https://doi.org/10.21276/sjhss.2019.4.8.4

Foster, B. (2017). Impact of Brand Image on Purchasing Decision on Mineral Water Product "Amidis" (Case Study on Bintang Trading Company). American Research Journal of Humanities and Social Sciences, 2(1), 1-11. https://doi.org/10.21694/2378-7031.16023

Gan, C., \& Wang, W. (2017). The influence of perceived value on purchase intention in social commerce context. Internet Research, 27(4), 772-785. https://doi.org/10.1108/IntR-06-20160164

Hairiyah, S., \& Ali, H. (2017). Customer Decision Analysis in Taking Multipurpose Loan: Promotions, Locations and Credit Procedures ( A Case of the Bank " PQR Jakarta "). Saudi Journal of Business and Management Studies. https://doi.org/10.21276/sjbms.2017.2.3.6

Jeaheng, Y., Al-Ansi, A., \& Han, H. (2020). Impacts of Halal-friendly services, facilities, and food and Beverages on Muslim travelers' perceptions of service quality attributes, perceived price, satisfaction, trust, and loyalty. Journal of Hospitality Marketing and Management, 29(7), 787-811. https://doi.org/10.1080/19368623.2020.1715317

Kazmi, A., \& Mehmood, Q. S. (2016). The effect of electronic word of mouth communication and brand image on purchase intention: A case of consumer electronics in Haripur, Pakistan. Management Science Letters, 6, 409-508. https://doi.org/10.5267/j.msl.2016.5.003

Kim, E. J., Kim, S. H., \& Lee, Y. K. (2019). The effects of brand hearsay on brand trust and brand attitudes. Journal of Hospitality Marketing and Management, 28(7), 765-784. https://doi.org/10.1080/19368623.2019.1567431

Konuk, F. A. (2018). Price fairness, satisfaction, and trust as antecedents of purchase intentions towards organic food. Journal of Consumer Behaviour, 17(2), 141-148. https://doi.org/10.1002/cb.1697

Larasetiati, M., \& Ali, H. (2019). Model of Consumer Trust: Analysis of Perceived Usefulness and toward Repurchase Intention in Online Travel Agent. Journal of Economics and Finance, 3(8), 350-357. https://doi.org/10.21276/sjef.2019.3.8.5

Limakrisna, N., \& Ali, H. (2016). Model of Customer Satisfaction: Empirical Study At Fast Food Restaurants in Bandung. International Journal of Business and Commerce.

M, A., \& Ali, H. (2017). MODEL KEPUASAN PELANGGAN: ANALISIS KUALITAS PRODUK DAN KUALITAS LAYANAN TERHADAP CITRA MEREK PADA GIANT CITRA RAYA JAKARTA. Jurnal Manajemen. https://doi.org/10.24912/jm.v21i3.254

Maisah, \& Ali, H. (2020). Entrepreneurship culture development process: Implementation of Islamic education values in the Batik Jambi (case study in Seberang Jambi community). Talent Development and Excellence.

Mappesona, H., Ikhsani, K., \& Ali, H. (2020). Customer purchase decision model, supply chain management and customer satisfaction: Product quality and promotion analysis. International Journal of Supply Chain Management. 
Mosunmola, A., Adegbuyi, O., Kehinde, O., Agboola, M., \& Olokundun, M. (2019). Percieved value dimensions on online shopping intention: The role of trust and culture. Academy of Strategic Management Journal, 18(1), 1-20.

Novansa, H., \& Ali, H. (1926). Purchase Decision Model: Analysis of Brand Image, Brand Awareness and Price (Case Study SMECO Indonesia SME products). Saudi Journal of Humanities and Social Sciences. https://doi.org/10.21276/sjhss

Pappas, I. O. (2018). User experience in personalized online shopping: a fuzzy-set analysis. European Journal of Marketing, 52(7-8), 1679-1703. https://doi.org/10.1108/EJM-10-20170707

Prihartono, \& Ali, H. (2020). The promises ethics and marketing concept strategy as a competitive advantage on private higher education (A survey on perception of product attributes and promotion mix in Indonesia). Talent Development and Excellence.

Richardo, Hussin, M., Bin Norman, M. H., \& Ali, H. (2020). A student loyalty model: Promotion, products, and registration decision analysis-Case study of griya english fun learning at the tutoring institute in wonosobo central Java. International Journal of Innovation, Creativity and Change.

Riyanto, S., Adila, L., \& Ali, H. (2017). The Effect of Incentives And Job Enthusiasm To Productivity of Go-Jek Driver At PT . Go-Jek Indonesia. Journal of Research in Business and Management.

Rödiger, M., Plaßmann, S., \& Hamm, U. (2016). Organic consumers' price knowledge, willingness-to-pay and purchase decision. British Food Journal, 118(11), 2732-2743. https://doi.org/10.1108/BFJ-04-2016-0164

Rosyid, A. N., Djoko W, H., \& Widayanto. (2013). Pengaruh Kualitas Produk , Citra Merek , Harga dan Iklan Terhadap Keputusan Pembelian Sepeda Motor Honda Revo ( Studi Kasus pada Konsumen Sepeda Motor Honda Revo Astra Motor Kebumen ). Diponegoro Journal of Social and Politic, 1-8.

Setiawan, E. B., Wati, S., Wardana, A., \& Ikhsan, R. B. (2020). Building trust through customer satisfaction in the airline industry in Indonesia: Service quality and price fairness contribution. Management Science Letters, 10(5), 1095-1102. https://doi.org/10.5267/j.msl.2019.10.033

Setyadi, D. A. (2017). Build Customer Loyalty with CRM and Brand Image (Case Study on Giant Citra Raya). IOSR Journal of Business and Management, 19(01), 35-42. https://doi.org/10.9790/487x-1901043542

Sitio, T., \& Ali, H. (2019). Patient Satisfaction Model and Patient Loyalty: Analysis of Service Quality and Facility (Case Study at Rawamangun Special Surgery Hospital). Scholars Bulletin. https://doi.org/10.36348/sb.2019.v05i10.002

SiVARAM, M., Hudaya, A., \& Ali, H. (2019). Building a Purchase and Purchase Decision: Analysis of Brand Awareness and Brand Loyalty. Dinasti International Journal of Education Management And Social Science, 1(2), 235-248. https://doi.org/10.31933/DIJEMSS

Suhaily, L. (2017). EFFECT OF PRODUCT QUALITY, PERCEIVED PRICE AND BRAND IMAGE ON PURCHASE DECISION ( Study On Japanese Brand Electronic Product). $X X I(02), 179-194$. 
Sulistiorini, M. S., \& Ali, H. (2017). Customer satisfaction model: Product analysis, price, promotion and distribution (case study at PT Integrasia Utama). International Journal of Applied Business and Economic Research.

Suryana, S. (2010). Metodologi Penelitian. Universitas Pendidikan Indonesia, 58. https://doi.org/10.1007/s13398-014-0173-7.2

Susanty, A., Bakhtiar, A., \& Suliantoro, H. (2016). 6 atisfaction on 7 rust and / oyalty of , ndividual ) armers to ' airy \& ooperative Case 6 tudy ' airy 6 upply \& hain in Boyolali. 104108.

Thanh Nguyen, P., Ali, H., \& Agung Hudaya. (2019). MODEL BUYING DECISION AND REPEAT PURCHASE: PRODUCT QUALITY ANALYSIS (Case Study of Bank Permata Syariah Jakarta KPR Financing Customers). Dinasti International Journal of Management Science. https://doi.org/10.31933/dijms.v1i1.29

Yen, Y. S. (2019). Exploring the synergy effect of trust with other beliefs in television shopping. Management Decision, 58(3), 428-447. https://doi.org/10.1108/MD-11-2016-0814

Yu, C. C., Lin, P. J., \& Chen, C. S. (2013). How brand image, country of origin, and self-congruity influence internet users' purchase intention. Social Behavior and Personality, 41(4), 599-611. https://doi.org/10.2224/sbp.2013.41.4.599

Yunita, D., \& Ali, H. (2017). Model of Purchasing Decision ( Renting ) of Generator Set : Analysis of Product Quality, Price an Service at PT . Hartekprima Listrindo. Economics, Business and Management. https://doi.org/10.21276/sjebm.2017.4.11.12

Zhao, J. Di, Huang, J. S., \& Su, S. (2019). The effects of trust on consumers' continuous purchase intentions in $\mathrm{C} 2 \mathrm{C}$ social commerce: A trust transfer perspective. Journal of Retailing and Consumer Services, 50(January), 42-49. https://doi.org/10.1016/j.jretconser.2019.04.014 